\title{
The effect of ethanol on rat tongue and the possible protective role of royal jelly: Light and scanning electron microscopic study
}

\section{Original Article}

\author{
Zainab M. Altayeb ${ }^{1}$ and Maysara M. Salem ${ }^{2}$ \\ ${ }^{1}$ Histology and cell biology department, Faculty of Medicine, Helwan University. \\ ${ }^{2}$ Histology and Cell Biology Department, Faculty of Medicine, Benha University.
}

\begin{abstract}
Background: Ethanol is the most commonly used and abused xenobiotic in the world. Royal jelly (RJ) has been considered as an antioxidant that protects against different agents.

Aim of the work: This study aimed to investigate the effect of ethanol on the rat tongue and the possible protective role of royal jelly.

Material and methods: Twenty five adult male rats were used in this study and were divided into 4 groups. Group I: 10 rats were divided equally into negative and positive controls. Group II: 5 rats received RJ at a dose of $100 \mathrm{mg} / \mathrm{kg}$ body weight by gastric tube daily for 30 days. Group III: 5 rats received ethanol at a dose of $10 \mathrm{ml} / \mathrm{kg}$ body weight from $30 \% \mathrm{v} / \mathrm{v}$ ethanol solution in distilled water by a gastric tube daily for 30 days. Group IV: 5 rats received both RJ and ethanol as the same previous doses by gastric tube for 30 days. Tongue sections were histologically prepared and examined.

Results: The results revealed that group II was nearly as group I. Group III revealed by LM dorsal surface of the tongue was covered by irregularly arranged, short and long lingual papillae. Some papillae were thin, with blunted tips and others were completely absent. The epithelial lining of the ventral surface also showed an apparent reduction in thickness. The keratin layer of the ventral surfaces of the tongue appeared in some regions discontinuous and detached. Some skeletal muscle fibers revealed separations and vacuolations.

Scanning electron microscope (SEM) examination revealed a noticeable atrophy of lingual papillae from being short to being absent in focal areas. They were irregularly arranged in different directions. Group IV revealed amelioration of these changes. Conclusion: Ethanol has damaging effects on the lingual papillae and muscles and royal jelly has a protective role for these effects.
\end{abstract}

Key Words: Ethanol, Lingual papillae, Royal jelly

Revised: 18 April 2017, Accepted: 17 August 2017

Corresponding Author: Maysara Salem, Tel.: +201064470443, E-mail: maysara.m.salem@gmail.com, Department of Histology and Cell Biology, Faculty of Medicine, Benha University, Egypt

ISSN:1110-0559, September 2017, Vol. 40, No. 3

\section{INTRODUCTION}

Ethyl alcohol (ethanol) is the most commonly abused xenobiotic in the world. It is widely used among adolescents and adults of all socioeconomic groups, and represents a massive financial and social $\operatorname{cost}^{[1]}$. In addition to beverages, ethanol is present in hundreds of medicinal preparations used as a solvent or diluent in concentrations ranging from $0.3 \%$ to $75 \%$. Mouthwashes may contain up to $75 \%$ ethanol, and colognes typically contain $40 \%$ to $60 \%$ ethanol. These products occasionally cause intoxication, especially when accidentally ingested by children ${ }^{[2]}$.

Alcoholism is the leading cause of morbidity and mortality all over the world. For example, the prevalence of ethanol dependence in the United States has been relatively stable, at around $6 \%$ for men and $2 \%$ for women. The overall estimated cost of US health expenses related to ethanol is about 185 billion dollars per year. More than 200,000 Americans die yearly of alcoholism, far more than those who die of all illegal drugs of abuse combined. Ethanol is the leading cause of mortality in people aged 15 to 45 years $^{[2]}$.

It is well known that ethanol is a harmful agent which can damage many organs and cause serious health problems ${ }^{[3]}$. Long-term high consumption of ethanol causes behavioral changes, hyperactivity, mental retardation, depression, addiction, and cognitive dysfunction ${ }^{[4,5]}$.

The tongue is one of the anatomic sites with the highest risk for the evolution of oral cancer ${ }^{[6]}$. Alcohol is 
considered as a risk factor for oral malignancies. Some studies revealed that there is a relation with dose and/or duration of alcohol ingestion, but the exact mechanism for its carcinogenesis remains obscure ${ }^{[7]}$.

On the other hand, royal jelly (RJ) is a complex substance comprises a wonderful mixture of vitamins, minerals, amino acids, proteins (12-15\%), sugars $(10-12 \%)$ and lipids $(3-7 \%)^{[8]}$. RJ has many beneficial biological functions in experimental animals such as antioxidant ${ }^{[9,10]}$, antibacterial ${ }^{[11]}$, antiinflammatory ${ }^{[12]}$, antiallergic $^{[13]}$, antiaging ${ }^{[14]}$, antihypertensive ${ }^{[15]}$, and anticancerous properties ${ }^{[16]}$. Also, RJ contains steroids, phenols, acetylcholine and other unknown substances thus it is used in cosmetics for its alleged tonic and biostimulating effects ${ }^{[17]}$.

Recently, many investigators have reported that the antioxidant effect is an important ideal agent for healing of the wounds ${ }^{[18-20]}$. Inoue et al..$^{[9]}$ reported the ameliorative role of dietary RJ on DNA oxidative damage in mice. RJ has health promoting properties, studies have indicated that many major RJ proteins are major contributors for various physiological functions ${ }^{[21,22]}$.

Therefore, this study aimed to investigate the effect of ethanol on the rat tongue and the possible protective role of royal jelly by evaluating the histological changes by both LM and scanning EM.

\section{MATERIALS AND METHODS:}

\section{Drugs:}

Royal jelly: RJ 1000 mg capsules were obtained from Pharco Pharmaceuticals, Alexandria, Egypt.

Ethanol: Pure ethyl alcohol was obtained as a bottle contains 1 litre from El-Nasr Company for pharmaceutical industries, Egypt.

\section{Animals:}

The present study was carried out on 25 normal adult male albino rats, aged three months and their body weight ranged between 180 and 200 gms. They were obtained from the Animal House of Moshtohor Faculty of Veterinary Medicine, Benha University and acclimatized to the laboratory conditions. They were housed in plastic suitable cages with mesh wire covers under the prevailing atmospheric conditions and were given food and water ad libitum. Strict care and good hygiene were taken to maintain normal and healthy environment. The rats were sacrificed according to the Ethics Committee Recommendations of Benha University.

The animals were randomized divided into 4 groups.

Group I (Control group): 10 rats were divided into two subgroups each containing five animals:
Subgroup IA: kept as a negative control, they were left without intervention.

Subgroup IB: kept as a positive control, each animal was given $0.5 \mathrm{ml}$ of distilled water (the vehicle of RJ) by gastric tube for 30 consecutive days.

Group II: rats received RJ at a dose of $100 \mathrm{mg} / \mathrm{kg}$ body weight dissolved in $0.5 \mathrm{ml}$ distilled water by gastric tube for 30 consecutive days.

Group III: rats received ethanol at a dose of $10 \mathrm{ml} / \mathrm{kg}$ body weight from $30 \% \mathrm{v} / \mathrm{v}$ ethanol solution in distilled water daily by gastric tube for 30 consecutive days.

Group IV: rats received both $\mathrm{RJ}$ at a dose of $100 \mathrm{mg} / \mathrm{kg}$ body weight dissolved in $0.5 \mathrm{ml}$ distilled water and after 1 hour, received ethanol at a dose of $10 \mathrm{ml} / \mathrm{kg}$ body weight from $30 \% \mathrm{v} / \mathrm{v}$ ethanol solution in distilled water by gastric tube for 30 consecutive days. Twenty four hours after the end of experiment, animals in all groups were sacrificed by an overdose of intramuscular injection of sodium pentothal and their tongues were removed and the anterior 23/ of the tongues were dissected. After that, all specimens were longitudinally cut into two halves.

\section{Histological study:}

The tongues were prepared for light and scanning electron microscopic studies. The first halves of the tongues were fixed in $10 \%$ formal saline, dehydrated, cleared and embedded in paraffin wax. Sections of $5 \mu \mathrm{m}$ thick were cut and stained with haematoxylin and eosin (H\&E) to verify histological details ${ }^{[23]}$.

The second halves of the tongues were prepared for scanning electron microscopy. They were fixed in 5\% glutraldehyde. The specimens were then washed in 0.1 $\mathrm{M}$ cacodylate buffer and post-fixed in a solution of $1 \%$ osmium tetroxide at $37{ }^{\circ} \mathrm{C}$ for 2 hours. Subsequently, the specimens were treated with $3 \mathrm{~N}$ hydrochloric acid at 60 ؛ for 30 minutes to remove any extracellular mucus from lingual surface. This process was followed by dehydration, drying, and platinum-palladium ion-sputtering. Thereafter, all specimens were studied by SEM.

The SEM study was performed with a Jeol 1010 - JSM - 5500 LV scanning electron microscope (Japan) at the Regional Center for Mycology and Biotechnology, Al-Azhar University.

\section{RESULTS}

Group I:

Histological examination of $H \& E$ stained sections revealed that both subgroups IA and IB showed the same 
histological findings. The dorsal and ventral surfaces of the tongue were covered by keratinized stratified squamous epithelium setting on a basement membrane and a lamina propria formed of connective tissue. The dorsal surface of the anterior 23/ of the tongue had lingual papillae that revealed a thick epithelial covering with a thick keratin layer. The filiform papillae were conical in shape with tapering tips. They were the most numerous (Fig. 1), however, the fungiform papillae were few, short, with broad apices and distributed between the filiform ones. Taste buds were present on the upper surface of the fungiform papillae (Fig. 2).

The mucous membrane of the ventral surface had thin regular keratin layer without lingual papillae (Fig. 3). Underlying the covering epithelium of both the lingual dorsal and ventral surfaces, there was a connective tissue corium continuous with the connective tissue of the lingual muscles (Figs 1, 2 \& 3 ).

The skeletal muscle fibers constituted the main component of the tongue. They were composed of intermingled fascicles that directed in various directions to allow flexibility and free movements of the tongue (Figs 1, 2, $3 \& 4$ ). The connective tissue between muscle bundles contained few adipocytes (Fig. 4).

SEM SEM examination of control group showed that the dorsal surface was covered by elongated, numerous, conical shaped-filiform papillae with intact, slightly curved, tapering tips that pointed into one direction. (Fig. 5). Some fungiform papillae were appeared sporadically between the filiform papillae. They were short, broad in shape and had flattened smooth upper surface that was traversed by taste pores in the center (Figs $6,7 \& 8$ ). The epithelial cells on the surface of fungiform papillae had microfolds (Fig. 8).

Group II:

Examination of various sections in this group revealed that they were very similar to those of group I in their histological features.

\section{Group III:}

Sections of this group revealed patchy and variable histological changes. The dorsal surface of the tongue was covered by irregularly arranged short and long lingual papillae (Fig. 9). Some papillae appeared with blunted ends (Figs 9 \& 10), with partial thinning and loss of keratin (Fig. 11). Few areas appeared without their normal covering epithelium (Fig. 12). Keratin layer showed separation (Figs 9, 10, 12 \&13).

The epithelial lining of the ventral lingual surface revealed a noticeable decrease in its thickness. The keratin layer of the lingual ventral surface seemed in some regions thin, discontinuous and detached, with lack of its integrity (Fig. 14).

The skeletal muscle fibers were directed in various directions and revealed separation and vacuolation between fibers (Figs 10, $13 \& 16$ ), an apparent increased number of adipocytes (Figs $14 \& 16$ ). There were also congested blood vessels (Figs 11, 15\&16).

SEM examination of this group revealed damages in the filiform papillae which appeared thin atrophied, blunted edge or disfigured (Fig. 17). They appeared damaged and disrupted and irregularly arranged in different directions and the fungiform papillae appeared nearly normal (Figs 18, 19, 20 \&21). Filiform papillae were apparently absent in some few areas (Fig. 20).

\section{Group IV:}

Sections of this group showed good improvement of the histological picture in comparison to group III; most of filiform papillae appeared regularly arranged with intact tapering tips (Fig. 22). The ventral surface revealed normal thickness with normal covering keratin (Fig. 23). Most of the skeletal muscle fibers and bundles appeared comparable to those of the control group (Fig. 24).

SEM examination of this group revealed nearly normal appearance of lingual papillae compared to control group. They appeared as long, conical shaped, regularly arranged and directed nearly to one direction and mostly with intact tapering tips (Fig. 25). The fungiform papillae appeared apparently normal with intact smooth upper surface and visible taste pores (Fig. 26).

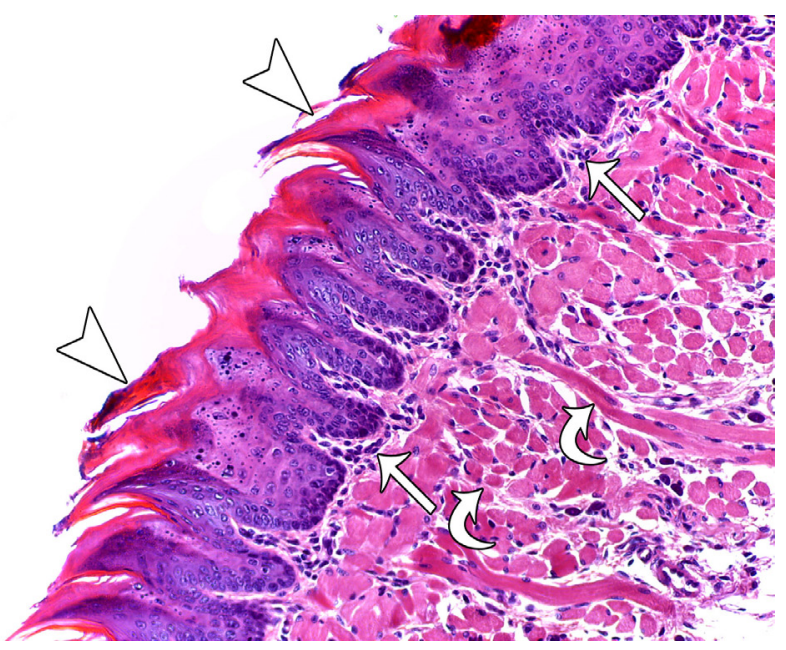

Fig. 1: A photomicrograph of the dorsal surface of a tongue of a rat from group I showing regular orientation of the filiform papillae which are covered by keratinized epithelium (arrow head). The underlaying lamina propria is formed of connective tissue $(\uparrow)$. The lingual muscle fibers run in different directions (bent arrow). 


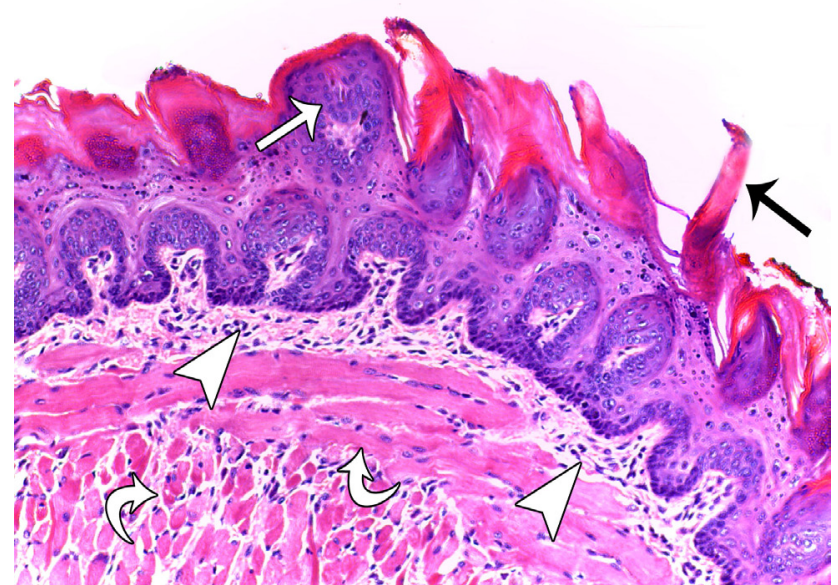

Fig. 2: A photomicrograph of dorsal surface of a tongue of a rat from group I showing sharp conical projections of filiform papillae (black $\uparrow$ ), a fungiform papilla showing intraepithelial taste bud on the upper surface $(\uparrow)$, lamina propria (arrow head) and skeletal muscle fibers run in different directions (bent arrows).

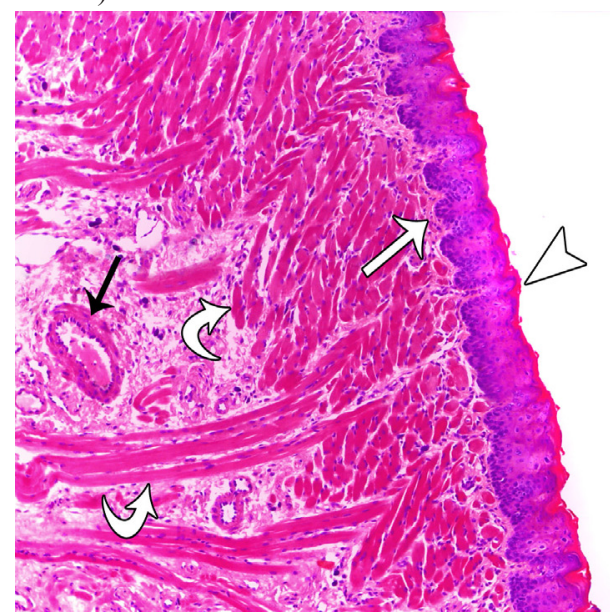

(H\&E X 200).

Fig. 3: A photomicrograph of ventral surface of a tongue of a rat from group I showing no lingual papillae and presence of thin regular keratin layer (arrow head). The under laying lamina propria is formed of connective tissue $(\uparrow)$. The lingual muscle fibers run in different directions (bent arrows) and black arrow denotes a blood vessel.

(H\&E X 100).

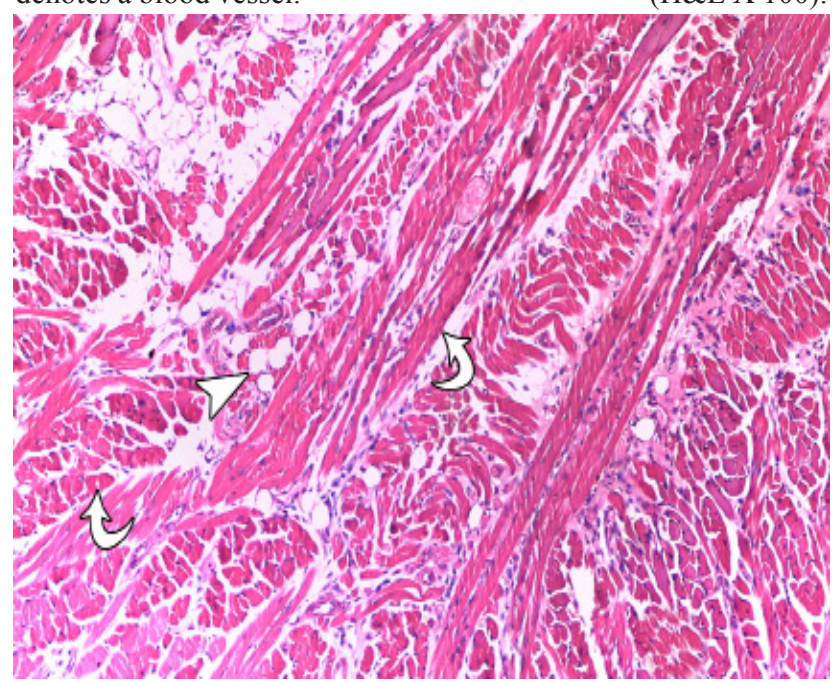

Fig. 4: A photomicrograph of a tongue of a rat from group I showing adipocytes (arrow head) between muscle fibers which run in various directions (bent arrows).

(H\&E X 100)

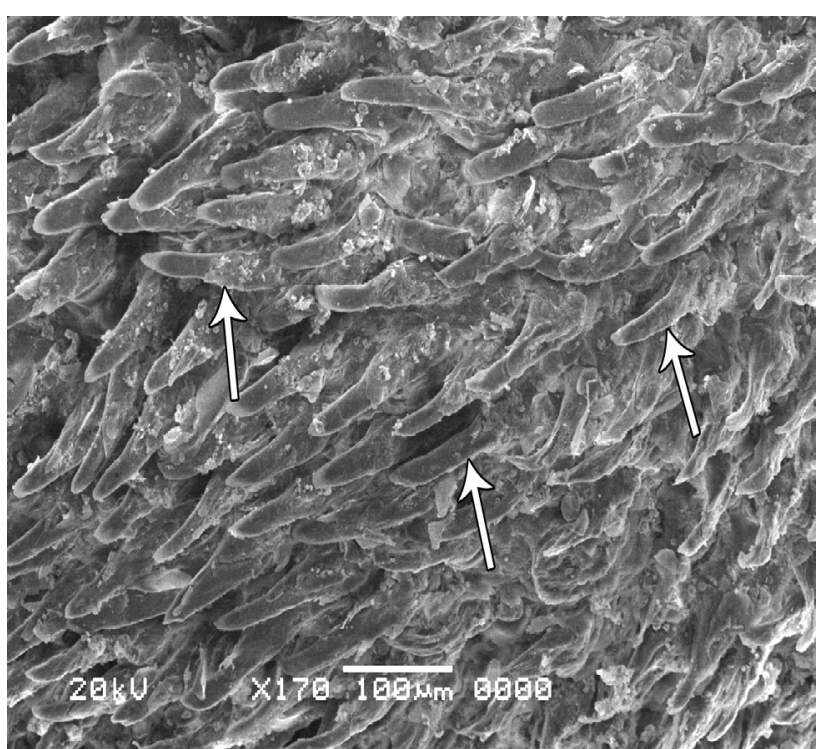

Fig. 5: A scanning electron micrograph of a tongue of a rat from group I showing regular orientation in one direction of long conical filiform papillae with tapering keratinized ends. X 170

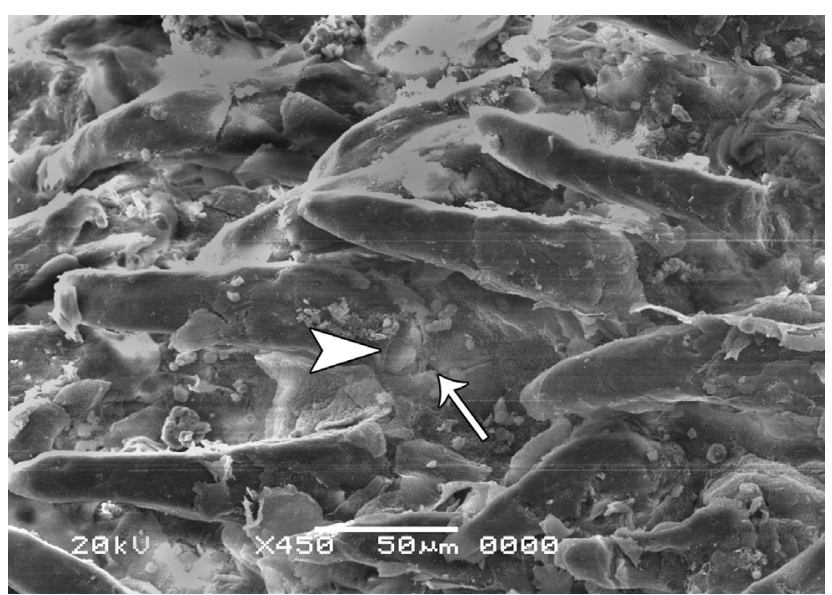

Fig. 6: A scanning electron micrograph of a tongue of a rat from group I showing multiple filiform papillae and a fungiform papilla (arrow head) and its taste pore $(\uparrow)$.

X 450 .

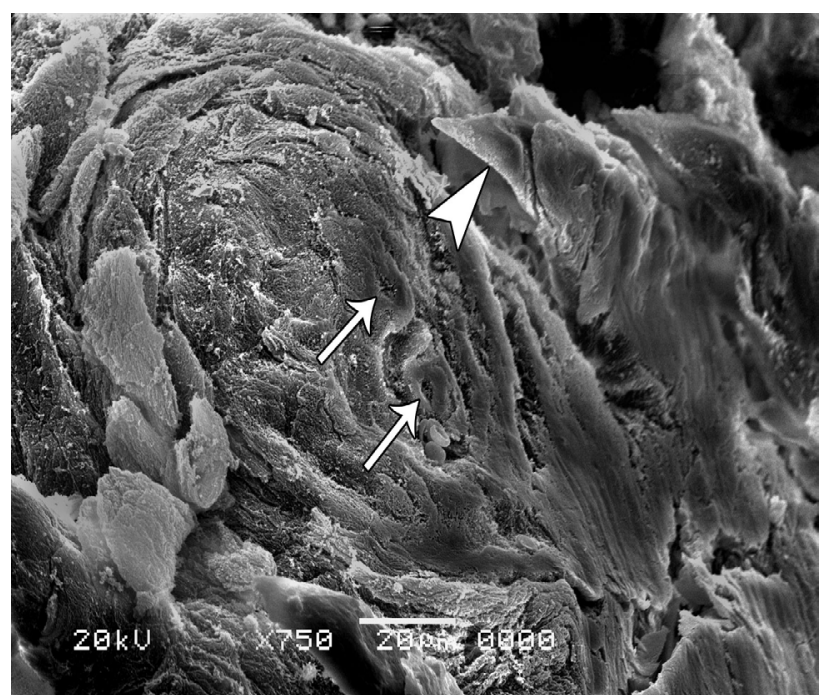

Fig. 7: A scanning electron micrograph of a tongue of a rat from group I showing a fungiform papilla with taste pores $(\uparrow)$ and a filiform papilla (arrow head).

X 750 


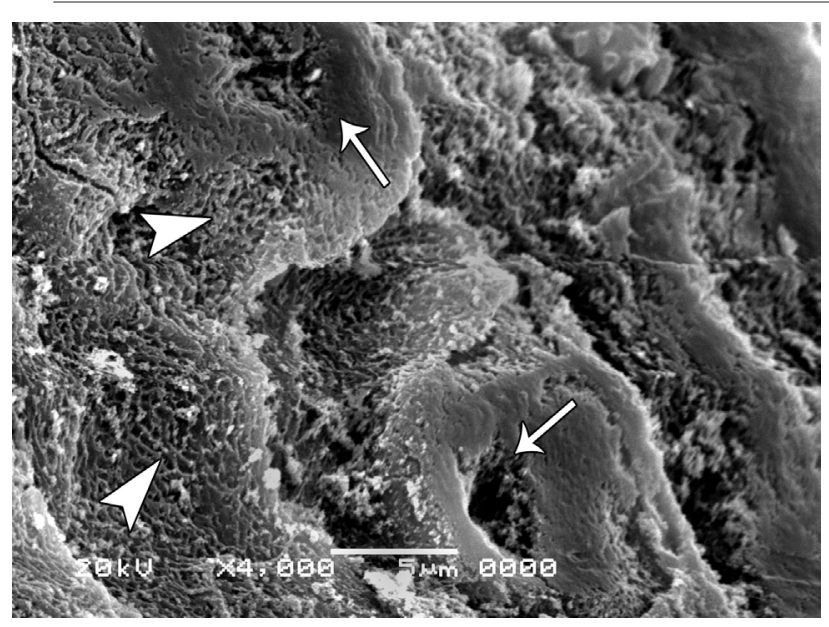

Fig. 8: A magnification of the previous figure showing the epithelial cells on the surface of a fungiform papilla with microfolds (arrow heads) and taste pores $(\uparrow) . \quad$ X 4000

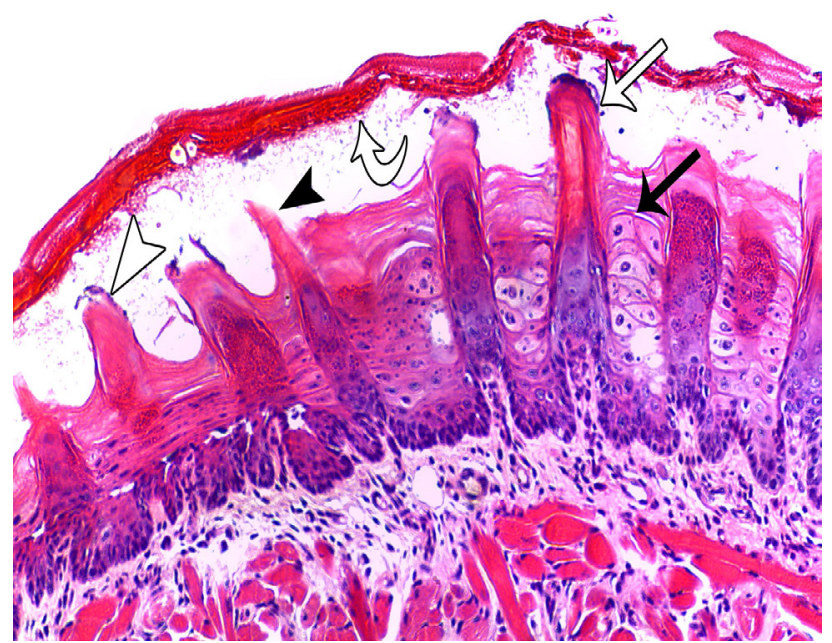

Fig. 9: A photomicrograph of dorsal surface of a tongue of a rat from group III showing short (arrow head), thin (black arrow head) and long filiform papillae with blunted ends $(\uparrow)$, with separated keratin covering (bent arrow). Black arrow denotes flat stratified epithelial cells. (H\&E X 200).

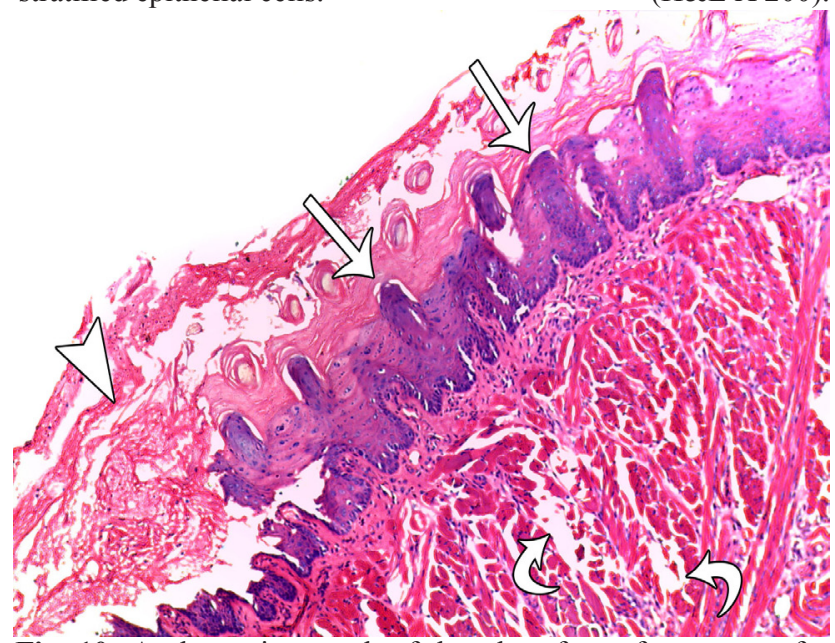

Fig. 10: A photomicrograph of dorsal surface of a tongue of a rat from group III showing the keratin cover is disfigured and separated in some areas (arrow head), some papillae have blunt ends ( $\uparrow$ ). Note separation between muscle fibers (bent arrows).

(H\&E X 100).

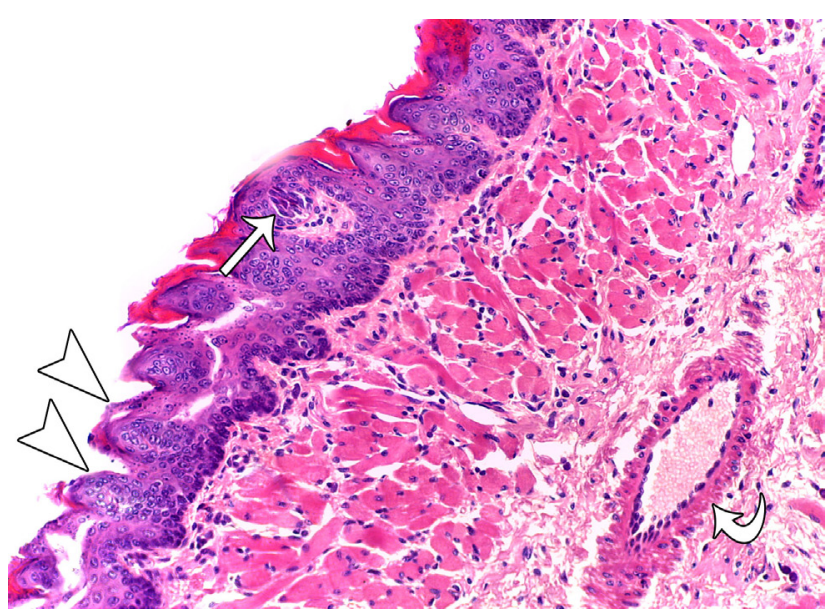

Fig. 11: A photomicrograph of dorsal surface of a tongue of a rat from group III showing filiform papillae, a fungiform papilla showing intraepithelial taste bud on the upper surface $(\uparrow)$, an area with partial thinning and loss of keratin (arrow head) and a congested blood vessel (bent arrow).

(H\&E X 200).

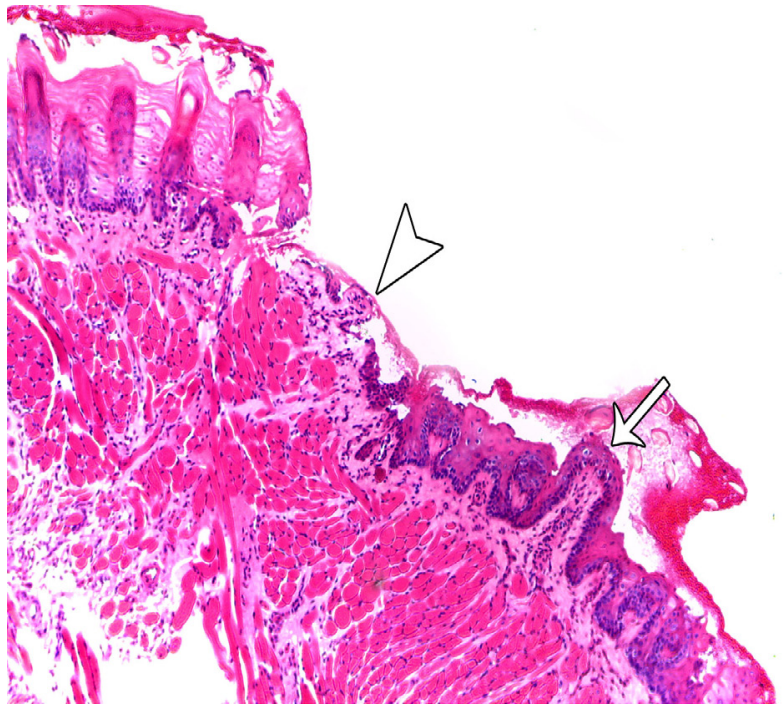

Fig. 12: A photomicrograph of dorsal surface of a tongue of a rat from group III showing a fungiform papilla with broad apex $(\uparrow)$ and an area that has lost its normal covering epithelium (arrow head).

(H\&E X 100).

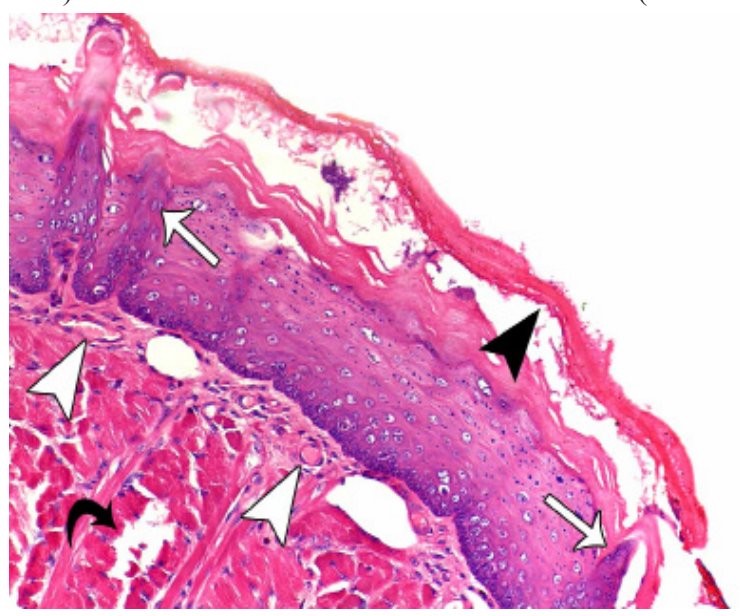

Fig. 13: A photomicrograph of dorsal surface of a tongue of a rat from group III showing focal area of flattening of the dorsal surface of the tongue with apparent short filiform papillae $(\uparrow)$. Keratin layer is separated (black arrow head) there are separation and vacuolations between muscle fibers (black bent arrow).

(H\&E X 200). 


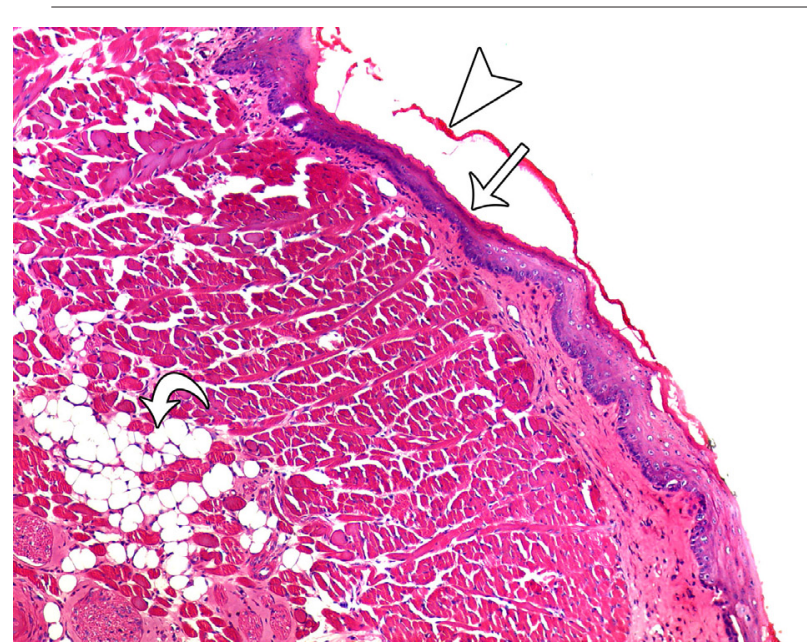

Fig. 14: A photomicrograph of ventral surface of a tongue of a rat from group III showing an irregular contour with thin epithelium ( $\uparrow$ ), thin keratin (black arrow head) and keratin layer separated in some area (white arrow head). The lingual muscle fibers run in different directions with accumulation of adipocytes (bent arrow). (H\&E X 100)..

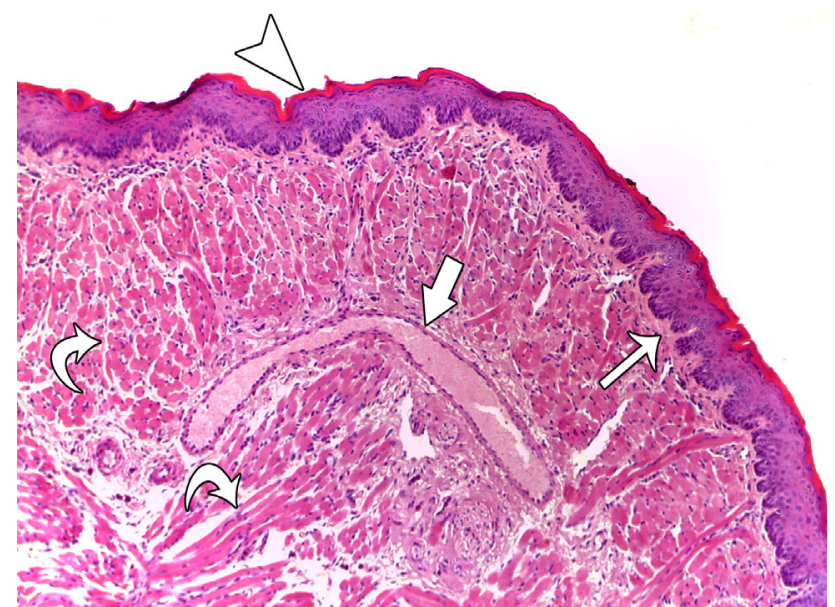

Fig. 15: A photomicrograph of ventral surface of a tongue of a rat from group III showing an irregular contour with thin keratin layer (arrow head). The under laying lamina propria is formed of connective tissue $(\uparrow)$. The lingual muscle fibers run in different directions (bent arrow) and contain congested blood vessel (thick arrow). (H\&E X 100).

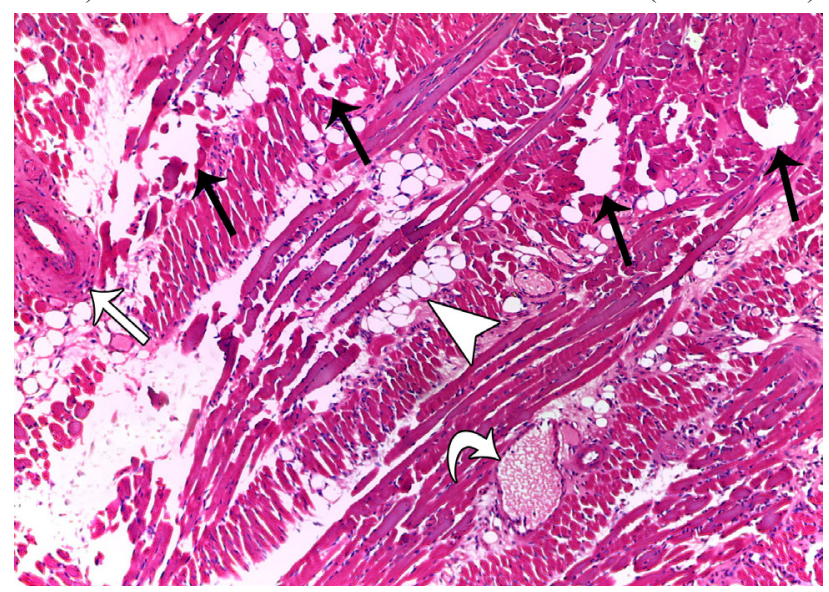

Fig. 16: A photomicrograph of a tongue of a rat from group III showing some vacuolations and separation in muscle bundles (black $\uparrow$ ), adipocytes (arrow head), an artery (white $\uparrow$ ) and congested venule (bent arrow).

$(\mathrm{H} \& \mathrm{E}$ X 100)

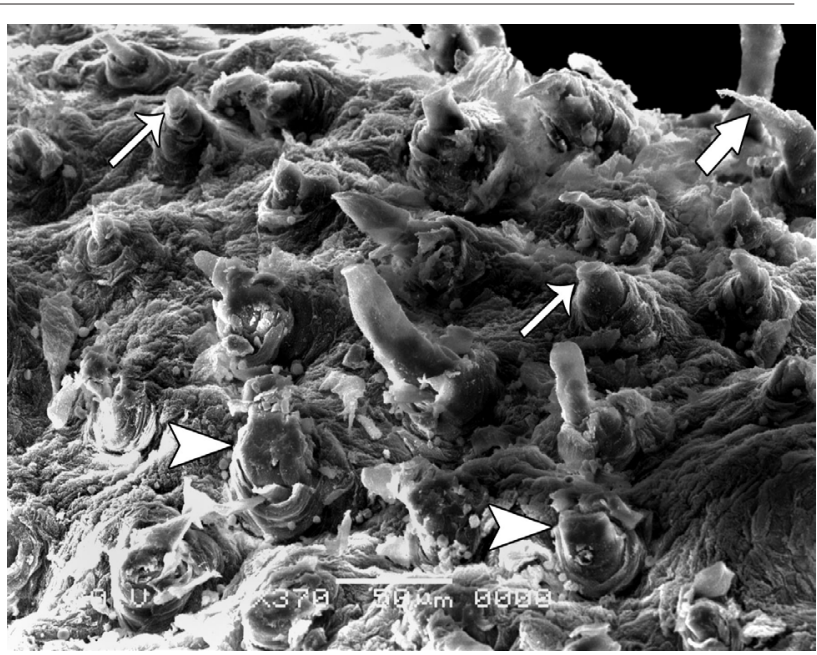

Fig. 17: A scanning electron micrograph of a tongue of a rat from group III showing damages in the filiform papillae; thin (thick arrow), blunted edge $(\uparrow)$ and disfigured papillae (arrow heads).

X 370 .

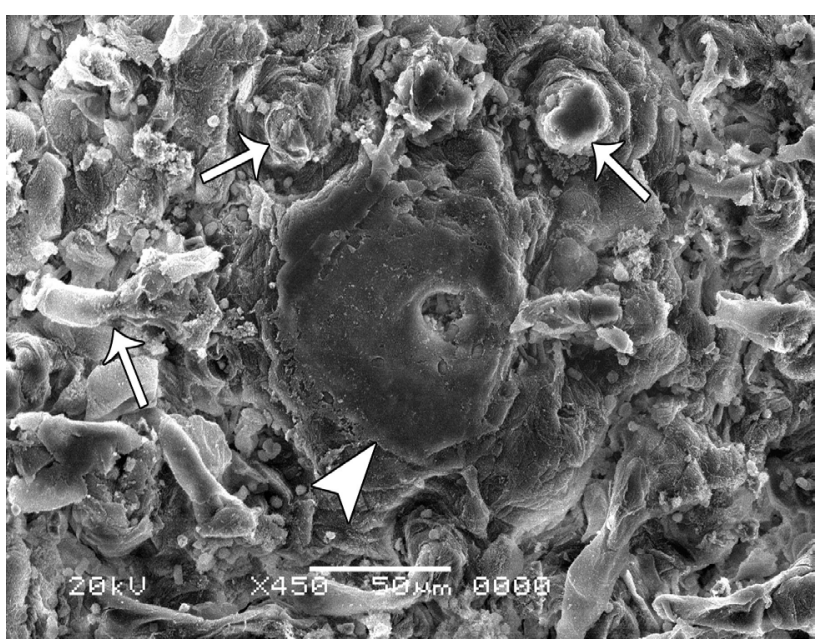

Fig. 18: A scanning electron micrograph of a tongue of a rat from group III showing damages and disruptions in the filiform papillae $(\uparrow)$ and a nearly normal fungiform papilla. $\quad$ X 450 .

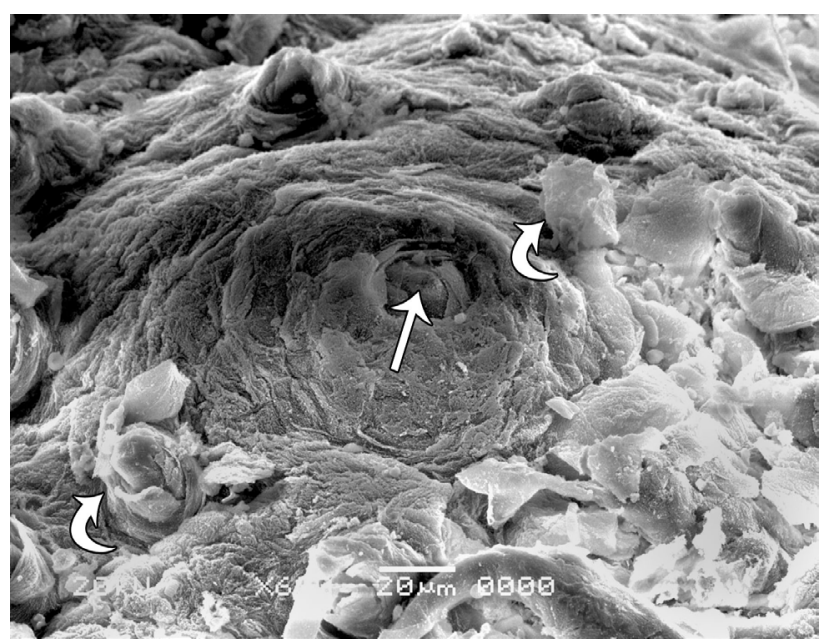

Fig. 19: A scanning electron micrograph of a tongue of a rat from group III showing a fungiform papilla with taste pore on top surface $(\uparrow)$. Filiform papillae appear destructed, short and irregular (bent arrow).

X 600 
Altayeb and Salem .

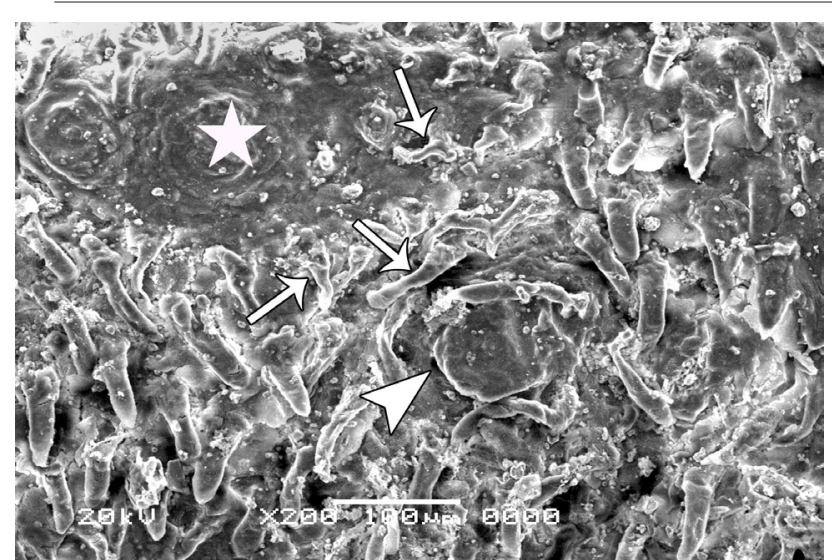

Fig. 20: A scanning electron micrograph of a tongue of a rat from group III showing a fungiform papilla (arrow head) has a hemispherical upper portion with a taste pore and irregular disorganized filiform papillae $(\uparrow)$. Note an area with apparent absence of papillae (star).

X 200

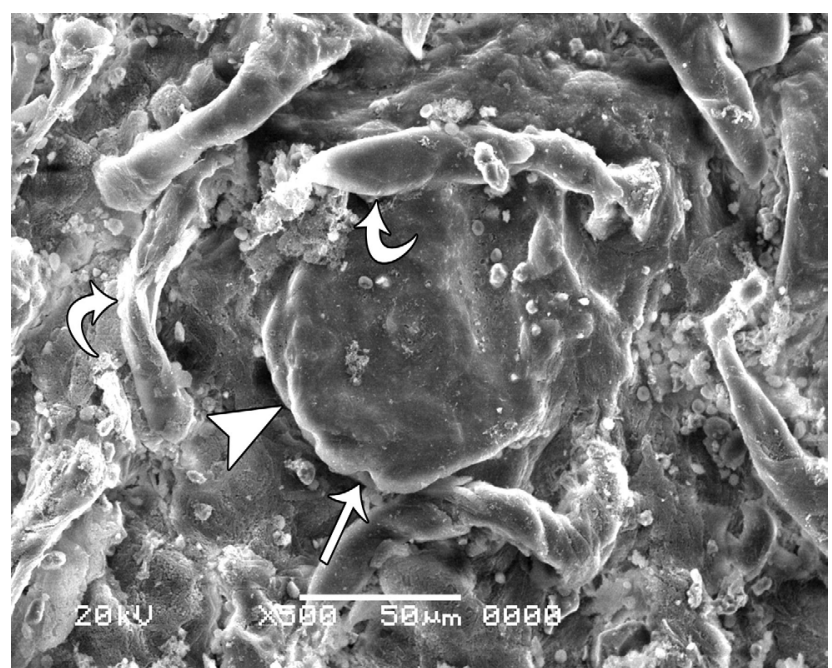

Fig. 21: A high magnification of the previous figure showing a fungiform papilla (arrow head) has a hemispherical upper portion with a taste pore $(\uparrow)$ and irregular disorganized filiform papillae (bent arrow).

X 500

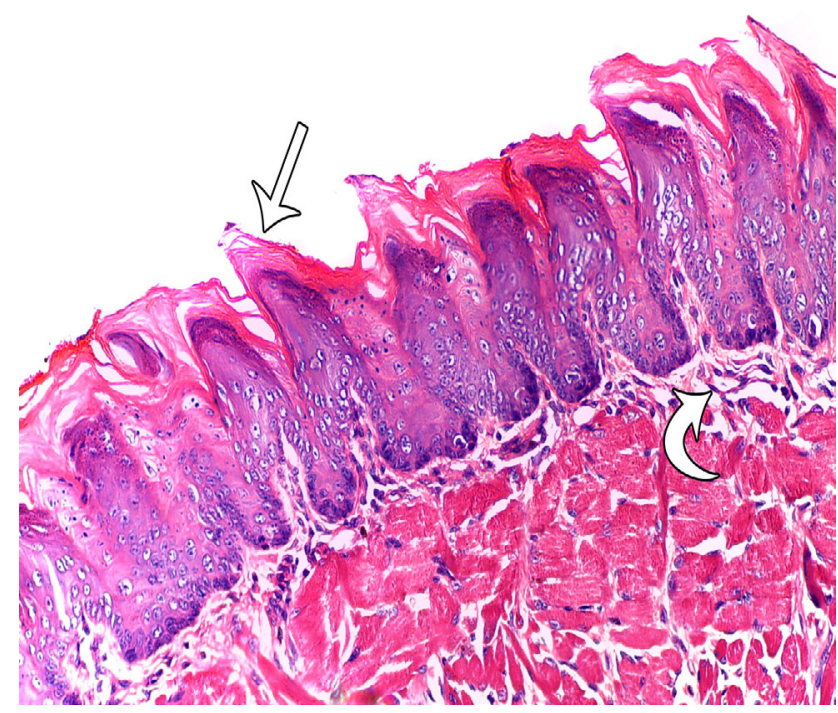

Fig. 22: A photomicrograph of the dorsal surface of a tongue of a rat from group IV showing nearly normal orientation of the filiform lingual papillae $(\uparrow)$. The underlaying lamina propria is formed of connective tissue.

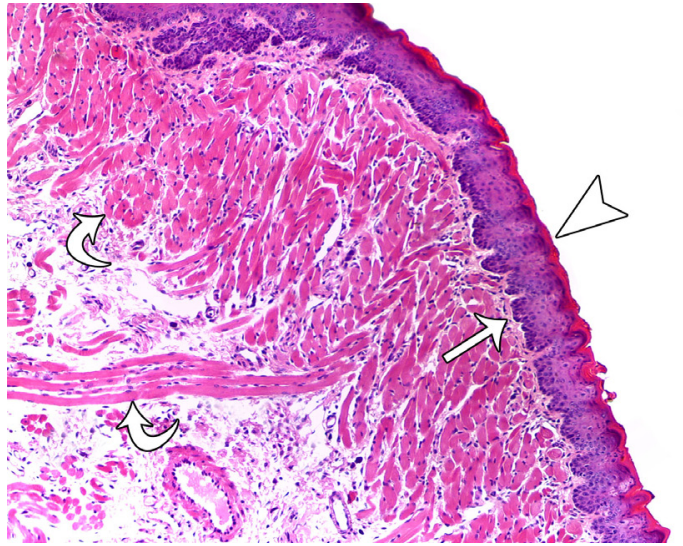

Fig. 23: A photomicrograph of ventral surface of a tongue of a rat from group IV showing presence of normal thin keratin layer (arrow head). The under laying lamina propria is formed of connective tissue $(\uparrow)$. The lingual muscle fibers run in different directions (bent arrow). (H\&E X 100)

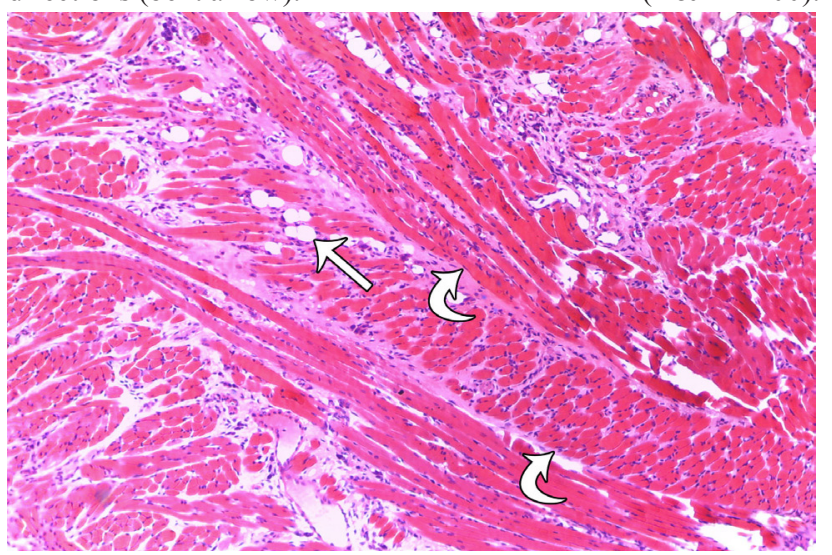

Fig. 24: A photomicrograph of a tongue of a rat from group IV showing adipocytes ((arrow head) between muscle fibers which run in various directions (bent arrows). (H\&E X 100).

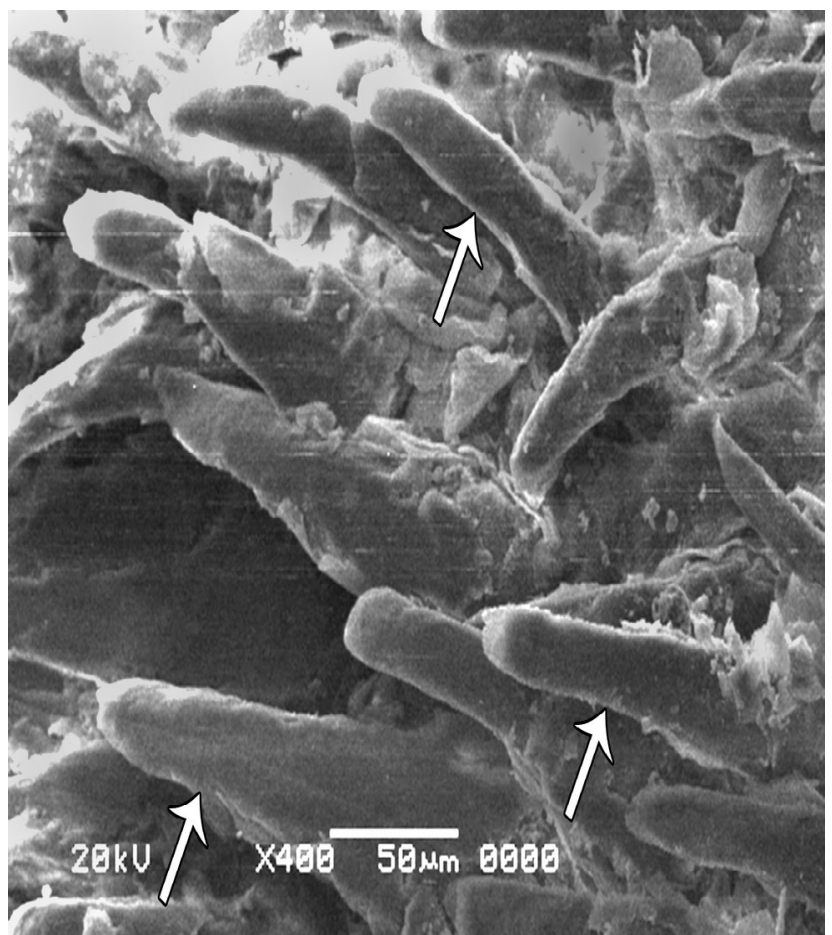

Fig. 25: A scanning electron micrograph of a tongue of a rat from group IV showing the filiform papillae $(\uparrow)$ nearly normal and their ends are directed in one direction. X 400 


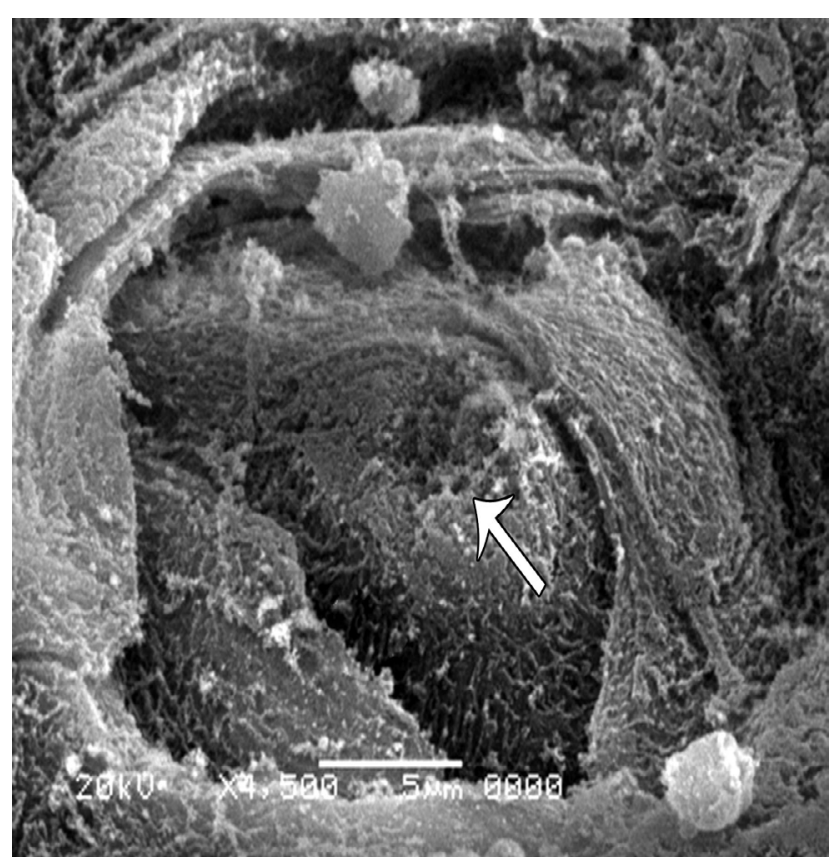

Fig. 26: A scanning electron micrograph of a tongue of a rat from group IV showing a fungiform papilla with a taste pore $(\uparrow) . \quad \mathrm{X}$ 4500

\section{DISCUSSION}

Ethanol is widely used all over the world and its problems impose a disturbing personal, social, and economic burden on society. Household violence, child abuse, falls, fires, sexual assault and dispossession, as well as medical sequels such as cancer, heart disease and liver disease have all been associated with ethanol misuse $^{[2]}$

The lifetime risk for repetitive ethanol problems is almost $11 \%$ for women and $20 \%$ for men, regardless of a person's education or income. High doses of ethanol increase the risk for vascular diseases and cancers. It is obvious that ethanol use disorders decrease the life span by about ten years ${ }^{[24]}$.

The tongue is considered as a mirror of the general personal health, especially the filiform papillae. Cells of these papillae have a high metabolic activity and so any nutritional deficiency, vascular changes or enzymatic disturbance lead to their atrophy. They undergo atrophic changes and damage faster and earlier before any other papillae ${ }^{[25]}$. Lingual atrophy may be a side-effect of a number of medications as antibiotics, or may be due to diabetes, cancer, anticancer drugs, chemical or metal toxicity ${ }^{[26]}$. Subsequently tongue had chosen in this study.

The present study revealed two types of lingual papillae, filiform and fungiform, in the anterior $2 / 3$ of the dorsal lingual surface. The vallate papillae were not observed in the current study owing to there is only one vallate papilla in rat's tongue that is present posteriorly in the midline. Also, foliate papillae are limited to the dorsolateral borders of the tongue, near the base so not observed in this study ${ }^{[27]}$.

The results of the group III revealed histological changes in the tongues of the rats in this group. An obvious shortening, thinning and atrophy of the lingual papillae were seen most probably due to decrease in the size and number of the epithelial cells covering the tongue. The epithelial covering of the dorsal and the ventral surfaces revealed an obvious decrease in their thickness. The covering keratin layer appeared thin and discontinuous with loss of its integrity. These changes are most probably attributed to oxidative stress exerted by ethanol. Oxidative stress has been proposed as playing a major role in many pathways of alcohol-induced damage in a variety of organs, such as liver ${ }^{[28]}$, testes ${ }^{[29]}$ and central nervous system ${ }^{[30]}$. Ethanol metabolism produces reactive oxygen species (ROS), which may injure several macromolecules in the cell such as proteins, DNA and lipids ${ }^{[31]}$.

It has been determined that ethanol consumption decreases antioxidant defenses and increases ROS production leading to oxidative stress in liver. Antioxidant enzymes exhibit diminished activity in addition to reduction in the cellular and extracellular content of non-enzymatic antioxidants. These antioxidants should be obtained by diet but they are not well absorbed by the digestive system because ethanol consuming ${ }^{[32]}$.

Bruckner et al. ${ }^{[33]}$ stated that ethanol is shown to induce an enzyme called cytochrome CYP2E1, which generates ROS that damage DNA, proteins and lipids. CYP2E1 also converts procarcinogens to carcinogens. Also, acetaldehyde which is a metabolite of ethanol has a carcinogenic effect to humans. It reacts with DNA forming adducts. Ethanol may also stimulate carcinogenesis by inhibiting DNA methylation and interfering with retinoic acid metabolism. Both smoking and ethanol act synergistically to cause oral, pharyngeal, and laryngeal malignances. It is generally accepted that ethanol induces liver carcinoma by causing cirrhosis or other chronic liver damage and/or by enhancing the bioactivation of other carcinogens.

The present study revealed that there were small accumulations of rounded adipocytes in between the muscle fibers. The results of a previous study showed that there was deterioration in oxidative capacity of mitochondria in ethanol consumption. This could reduce the ability of muscle to oxidize fat, leading to accumulation of lipid and adipocytes ${ }^{[34]}$.

Carrard et al. ${ }^{[35]}$ suggested that short-term alcohol consuming modifies the cellular lipid metabolism. 
Long period of alcohol administration should be achieved in order to determine the chronic effects on rat tongue mucosa.

The present study revealed some vacuolations and muscle separation between muscle fibers; these findings are in consistent with other investigators ${ }^{[36-38]}$ who stated that chronic alcoholic consumption leads to muscular damage. For example, myopathy occurs in $40-60 \%$ of patients who intake alcohol, and is associated by decreased muscular efficiency and skeletal muscle atrophy. The changes in alcoholic muscle disease are most probably due to the direct effect of ethanol or its metabolites. Acetaldehyde decreases muscular protein synthesis in vivo and increases the formation of acetaldehyde protein adducts in alcoholic myopathy.

The mechanisms by which ethanol affects the muscle include; gene dysregulation, disturbances of energy cell turnover and initiation of apoptosis. Pathologic abnormalities include degeneration and necrosis of individual muscle fibers, particularly type II fibers ${ }^{[39]}$.

The The results of group IV revealed amelioration of the deleterious effect of ethanol on the lingual papillae and lingual muscles. This amelioration can be attributed to the antioxidant properties of RJ. It includes major proteins with high contents of essential amino acids and peptides having high antioxidant and scavenging properties against free radicals ${ }^{[40]}$. Also, the antioxidant activity and biological benefits are due to polyphenols and phenols as flavonoids in major protein structures $^{[41,42]}$.

Moreover, Watanabe et al. ${ }^{[43]}$ reported that $\mathrm{RJ}$ is a potent scavenger for superoxide radicals, 1, 1-diphenyl2-picrylhydrazyl radicals, and hydroxyl radicals. Thus, in the healing effect of RJ on mucositis, free radical scavenging activity is an important factor. Moreover, some authors stated that RJ has antiinflammatory actions through inhibiting proinflammatory cytokine production from activated macrophages ${ }^{[44,45]}$.

\section{CONCLUSION}

Chronic ethanol consumption has damaging effects on the lingual papillae and lingual muscles. On the other hand, royal jelly has a protective role towards these effects.

\section{CONFLICT OF INTEREST}

There are no conflicts of interest

\section{REFERENCES}

1. Welch C, Harrison D, Short A, Rowan K. The increasing burden of alcoholic liver disease on United Kingdom critical care units: secondary analysis of a high quality clinical database. J Health Serv Res Policy 2008;13 (suppl 2):40- 44.

2. Yib L. Ethanol. In: Hoffman RS, Howland MA, Lewin NA, Nelson LS, Goldfrank LR, editors. Goldfrank's toxicologic emergencies, $10^{\text {th }}$ ed. Ch. 80, McGraw Hill education, New York, Chicago San, Francisco, Lisbon, London, Madrid, 2015; 1082- 1090.

3. Guo R, Jun R. Alcohol and acetaldehyde in public health: from marvel to menace. International Journal of Environmental Research and Public Health. 2010; 7(4): $1285-1301$.

4. Cushman JD, Moore MD, Jacobs NS, Olsen RW, Fanselow MS. Behavioral pharmacogenetic analysis on the role of the $\alpha 4 \mathrm{GABAA}$ receptor subunit in the ethanol-mediated impairment of hippocampus-dependent contextual learning. Alcoholism: Clinical and Experimental Research 2011; 35 (11):1948- 1959.

5. Wang P, Luo Q, QiaoH, Ding H, Cao Y., Yu J, Liu R, Zhang Q, Zhu H, Qu L. The neuroprotective effects of carvacrol on ethanol-induced hippocampal neurons impairment via the antioxidative and antiapoptotic pathways. Oxidative Medicine and Cellular Longevity 2017; Volume 2017, Article ID 4079425, 17 pages.

6. Turati F, Garavello W, Tramacere I, Bagnardi V, Rota M, Scotti L, Islami F, Corrao G, Boffetta P, La Vecchia C, Negri E. A metaanalysis of alcohol drinking and oral and pharyngeal cancers. Part 2: Results by subsites. Oral Oncol 2010; 46: 720-726.

7. Goldstein BY, Chang SC, Hashibe M, La Vecchia C, Zhang ZF. Alcohol consumption and cancers of the oral cavity and pharynx from 1988 to 2009: An update. Eur J Cancer Prev 2010; 19: 431- 465.

8. Morita H, Ikeda T, Fujioka K, Mori I, Okada H, Uno Y, Ishizuka T. Effect of royal jelly ingestion for six months on healthy volunteers, Nutrition Journal 2012; 11(1): article 77.

9. Inoue SI, Miyata SK, Ushio S, Iwaki K, Ikeda M, Kurimoto M. Royal Jelly prolongs the life span of $\mathrm{C} 3 \mathrm{H} / \mathrm{HeJ}$ mice: correlation with reduced DNA damage, Experimental Gerontology 2003; 38 (9): 965- 969.

10. Nakajima $Y$, Tsuruma $K$, Shimazawa $M$, Mishima S, Hara H. Comparison of bee products based on assays of antioxidant capacities. BMC Complementary and Alternative Medicine 2009; 9, article 4. 
11. Tseng JM, Huang JR, Huang HC, Tzen JTC, Chou WM, Peng CC. Facilitative production of an antimicrobial peptide royalisin and its antibody via an artificial oil-body system. Biotechnology Progress 2011; 27(1): 153- 161.

12. Kohno K, Okamoto I, Sano O, Arai N, Iwaki K, Ikeda M, Kurimoto M. Royal jelly inhibits the production of proinflammatory cytokines by activated macrophages, Bioscience, Biotechnology and Biochemistry 2004; 68(1): 138- 145.

13. Okamoto I, Taniguchi Y, Kunikata T, Kohno K, Iwaki K, Ikeda M, Kurimoto M. Major royal jelly protein 3 modulates immune responses in vitro and in vivo Life Sciences 2003; 73(16): 2029- 2045.

14. Park HM, Cho MH, Cho Y, Kim SY. Royal jelly increases collagen production in rat skin after ovariectomy. Journal of Medicinal Food 2012;15(6): 568 -575.

15. Tokunaga KH, Yoshida C, Suzuki KM, Maruyama H, Futamura Y, Araki Y, Mishima S. Antihypertensive effect of peptides from royal jelly in spontaneously hypertensive rats. Biological and Pharmaceutical Bulletin 2004; 27(2): 189 -192.

16. Mobasseri M, Ghiyasvand S, Ostadrahimi A, Ghojazadeh M, Noshad H, Pourmoradian S. Effect of fresh royal jelly ingestion on glycemic response in patients with type 2 diabetes. Iran Red Crescent Med J. 2015 September; 17(9):1-5.

17. Kausar SH, More VR, Ali SR. Spectrophotometric analysis of total protein content in fresh and lyophilised royal jelly. Journal of Medicinal Chemistry and Drug Discovery 2017; 3(2): 442-450.

18. Deniz M, Borman H, Seyhan T, Haberal M. An effective antioxidant drug on prevention of the necrosis of zone of stasis: N-acetylcysteine. Burns 2013; 39(2): 320 -325.

19. Hsiao CY, Hung CY, Tsai TH, Chak KF. A study of the wound healing mechanism of a traditional Chinese medicine, Angelica sinensis, using a proteomic approach. EvidenceBased Complementary and Alternative Medicine 2012; 2012, Article ID467531, 14 pages.

20. Lee YH, Chang JJ, Chien CT, Yang MC, Chien HF. Antioxidant sol-gel improves cutaneous wound healing in streptozotocin-induced diabetic rats. Experimental Diabetes Research 2012; 2012 Article ID 504693, 11 pages.
21. Schonleben S, Sickmann A, Mueller MJ, Reinders J. Proteome analysis of Apis mellifera royal jelly. Anal Bioanal Chem 2007; 389:1087- 1093.

22. Chiu HF, Chen BK, Lu YY, Han YC, Shen YC, Venkatakrishnan K, Golovinskaia O,Wang CK. Hypocholesterolemic efficacy of royal jelly in healthy mild hypercholesterolemic adults, Pharmaceutical Biology 2016; 55(1):497 -502.

23. Bancroft JD, Layton C. The hematoxylin and eosin. In: Suvarna SK, Layton C, Bancroft JD, editors. Theory \& practice of histological techniques. $7^{\text {th }}$ ed. Ch 10. Philadelphia, Churchill Livingstone, 2013; 172- 186.

24. Schuckit MA. Alcohol and Alcoholism. In: Kasper DL, Fauci AS, Hauser SL, Longo DL, Jameson JL, Lascalzo J. editors. Harrison's principles of internal medicine, $19^{\text {th }}$ ed., McGrow Hill Education, New York, Chicago, San Francisco, Lisbon, London, Madrid, 2015; 2723- 2728.

25. Osman HI, Abdel-Razek N, Koura SA Histological changes of rat lingual papillae due to chromium toxicity and the protective role of vitamin E. Egypt Dent J 2006; 52:193- 200.

26. Järvinen J, Kullaa-Mikkonen A, Kotilainen R. Some local and systemic factors related to tongue inflammation. Proc Finn Dent Soc 1989; 85:199-209.

27. Picut CA, Coleman GD. Gastrointestinal tract. In Parker GA, Picut CA, editors. Atlas of histology of the juvenile rat. $1^{\text {st }}$ ed. Ch. 5, Elsevier Inc. Amsterdam, Boston, Heidelberg, London, New York, Oxford, 2016; P. 128.

28. Dey A, Cederbaum AI. Alcohol and oxidative liver injury. Hepatology 2006;43 (2Suppl. 1), S63-S74.

29. Nordmann R, Ribière C, Rouach H. Ethanolinduced lipid peroxidation and oxidative stress in extrahepatic tissues. Alcohol 1990; 25:231- 237.

30. Chu J, Tong M, de la Monte SM. Chronic ethanol exposure causes mitochondrial dysfunction and oxidative stress in immature central nervous system neurons. Acta Neuropathol 2007; 113: 659 -673.

31. Das SK, Vasudevan DM. Alcohol-induced oxidative stress. Life Sci. 2007; 81: 177- 187.

32. Wu D, Cederbaum AI. Alcohol, oxidative stress, and free radical damage. Alcohol Res. Health 2003; 27 (4): 277 -284. 
33. Bruckner JV, Anand SS, Warren DA. Ethanol, Toxic effects of solvents and vapors. In: Klaassen CD, editor. Casarett and Doull's Toxicology, The basic science of poisons, 8 th ed. Ch. 24, McGraw Hill education, New York, Chicago, San Francisco, Lisbon, London, Madrid, 2013; 1069- 1072.

34. Morino K, Petersen KF, Shulman GI. Molecular mechanisms of insulin resistance in humans and their potential links with mitochondrial dysfunction. Diabetes 2006; 55 (Suppl 2): S9-S15.

35. Carrard VC, Pires AS, Mendez M, Mattos F, Moreira JCF, Sant'Ana Filho M. Effects of acute alcohol consumption and vitamin E co-treatment on oxidative stress parameters in rats tongue. Food and Chemical Toxicology 2009; 47:1058- 1063.

36. Preedy VR, Adachi J, Ueno Y, Ahmed S, Mantle D, Mullatti N, Rajendram R, Peters TJ. Alcoholic skeletal muscle myopathy: definitions, features, contribution of neuropathy, impact and diagnosis. Eur J Neurol. 2001; 8(6): 677- 687.

37. Preedy VR, Crabb DW, Farrés J, Emery PW. Alcoholic myopathy and acetaldehyde. Novartis Found Symp. 2007; 285:158-177; discussion 177-182, 198-199.

38. Nemirovskaya TL, Shenkman BS, Zinovyeva oE, Kazantseva IuV, Samkhaeva ND. The development of clinical and morphological manifestations of chronic alcoholic myopathy in men with prolonged alcohol intoxication. Fiziol Cheloveka 2015; 41(6):65 -69.
39. Crowther-Radulewicz CL and McCance KL. Alterations of Musculoskeletal Function, Toxic Myopathies. In: McCance KL, Huether SE, Brashers VL, Rote NS. Editors, Pathophysiology the biologic basis for disease in adults and children, $7^{\text {th }}$ ed. Ch. 44, Elsevier, USA, Canada, 2014; P 1585.

40. Guo H, Ekusa A, Iwai K, Yonekura M, Takahata Y, Morimatsu F. Royal jelly peptides inhibit lipid peroxidation in vitro and in vivo. J Nutr Sci Vitaminol (Tokyo) 2008; 54: 191 -195.

41. Ghanbari E, Nejati V, Khazaei M. Antioxidant and protective effects of royal jelly on histopathological changes in testis of diabetic rats. Int $\mathrm{J}$ Reprod BioMed 2016; 14 (8): 519-526.

42. Watanabe S, Suemaru K, Takechi K, Kaji H, Imai $\mathrm{K}$, Araki $\mathrm{H}$. Oral mucosal adhesive films containing royal jelly accelerate recovery from 5 -fluorouracilinduced oral mucositis. Journal of Pharmacological Sciences 2013; 121, (2): 110-118.

43. Kohno K, Okamoto I, Sano O, Arai N, Iwaki K, Ikeda M, Kurimoto M. Royal jelly inhibits the production of proinflammatory cytokines by activated macrophages. Bioscience, Biotechnology and Biochemistry 2004; 68 (1): 138- 145.

44. Yamauchi K, Kogashiwa Y, Moro Y, Kohno N. The effect of topical application of royal jelly on chemoradiotherapy-induced mucositis in head and neck cancer: A preliminary study. International Journal of Otolaryngology 2014; 2014, Article ID 974967, 5 pages. 


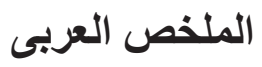

\section{تأثير الكحول الإثيلى على لسان الجرذ والتأثير الحمائى المحتمل لغذاء ملكات النحل، دراسة بالمجهر الضوئح والإكترونى الماستح}

\section{زينب محمد الطيب' ، ميسرة محمود سالمُ}

\section{اقسم الأنسجة ويبيولوجيا الخلية كلية الطب جامعة حلوان بقسم الأنسجة وبيولوجيا الخلية كلية الطب جامعة بنها}

المقدمة: يعتبر الكحول الإثيلى من المو اد (الغير موجودة بجسم الكائن الحي بصورة طبيعية) الأكثر استخداما فى العالم سواء كان استخداما صحيحا أو غبر صحيح وغذاء ملكات النحل مضاد للأكسدة له القدرة على الحماية من عو امل مختلفة. الهدف: تهدف هذه الدر اسة إلى بحث تأثير الإيثانول على لسان الجرذ، و التأثير الحمائى لغذاء ملكات النحل. الطرق والمواد المستخدمة: استخدم فى هذه الدر اسة 25 جرذا أبيض ذكر ا بالغا، وقد قسمو ا إلى أربع مجموعات. المجموعة

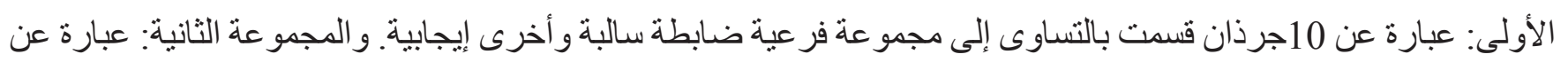
5 جرذان أعطيت غذاء ملكات النحل بجر عة قدر ها 100 مليجر ام/كيلوجر ام من وزن الجسم بواسطة الأنبوب المعدى لمدة 30 يو ما. و أما المجموعة الثالثة: فهى عبارة عن 5 جرذان أعطيت الإيثانول بجر عة قدر ها 10 مليلتر/كيلو جر ام من وزن الجسم من محلول كحولى 30 \% مذابا فى الماء المقطر بواسطة الأنبوب المعدى لمدة 30 يوما. و المجموعة الرابعة: عبارة عن 5 جرذان أعطيت غذاء الملكات ثم الإيثانول بنفس الجر عات السابقة لمدة 30 يوما وتم إعداد قطاعات من اللسان للفحص النسيجى. النتائج: أظهرت النتائج أن المجموعة الثانية كانت نتائجها ممالثة تقريبا للمجموعة الأولى، وأظهرفحص المجموعة الثالثة بالمجهر الضوئى عدم انتظام توزيع حلمات اللسان بالسطح العلوى للسان، وكان منها القصبرة والطويلة، وبعض الحلمات كان رفيعا ونهايتها الطرفية غليظة، وبعض الحلمات لم يكن موجودا. و أظهرت البطانة الظهارية للسطح السفلى قلة سمك هذه البطانة، و أظهرت طبقة الكر اتين للسطح السفلى عدم تو اصلهاو انفصالها فى بعض المو اضع. كما أظهرت بعض ألباف العضلات الهيكلية تجويفات و انفصالا عن بعضها البعض. وقد أظهر الفحص بالمجهر الإلكترونى الماسح للمجوعة الثالثة ضمور بحلمات اللسان التي كان منها القصير ومنها من لم يكن موجودا في بعض المناطق، وكانت الحلمات غبر منتظمة وتاخذ اتجاهات مختلفة.

$$
\text { وأظهرت المجمو عة الر ابعة تحسنا لهذه التغيرات. }
$$

الاستتتاج: للإيثانول تأثير ات ضارة بحلمات اللسان و عضلاته، و غذاء الملكات له تأثير حمائى ضد هذه الآثار الضارة. 